Atlantic Ocean and on the evontual movements of the continents ${ }^{8,8}$.

\section{JOANNES RASMUSSEN}

Føroyar Jardfrædissavn, Thorshavn.

ARne Noe-NygaARD

Mineralogisk Museum, Universitotet, Kobenhavn.

${ }^{2}$ Noe-Nygaard, A., Quart. J. Geol. Soe., Nomdon, 118 (1062),

${ }^{2}$ Rasmussen, J., in North Atlantic Biota and their History (Oxford, 1963),

" Bogrild, O. B., in Summary of the Geology of Denmark, D.G.V., V.R. 4 (1928).

4 Hart., N., Medd Dansk. Geol, Foren. 2, No. $3(1003)$

- Koch, E., and Rasmussen, J., Soc, Sci, Faeroensis, Bok. 12 (1963).

${ }^{*}$ Noc-Nygaard, A., Medd. Darsk. Geol. Foren., 9, No. 5 (1940).

"Lauteld, S., Geol. Fören. Förh., 87 (1965).

${ }^{\circ}$ Wilson, J. T., Scientific Amer, 208 (1963).

'Wilson, J. T, I.C.S.U. Review of World Science, 6, No. 1 (1964).

\section{Palaeocurrents in the Upper Cambrian of North Wales}

Is a recent cornmunication, Crimes and Sly ${ }^{1}$ comment on the variation of current pattorns in the Cambrian of North Wales. As a contribution to a better knowledge of these current directions this communication records some results obtained by us at difforont timos from work on tho Mrontwrog and Ffestiniog Beds (Upper Cambrian) of North Wales.

The hard siliceous siltstones and greywackes from those beds show many turbidite structures; for example, sharp lower junctions, diffuse upper junctions, graded and convolute bedding, eross-stratification, sub-aqueous slumping, bioturbation, and a varioty of sole markings, including

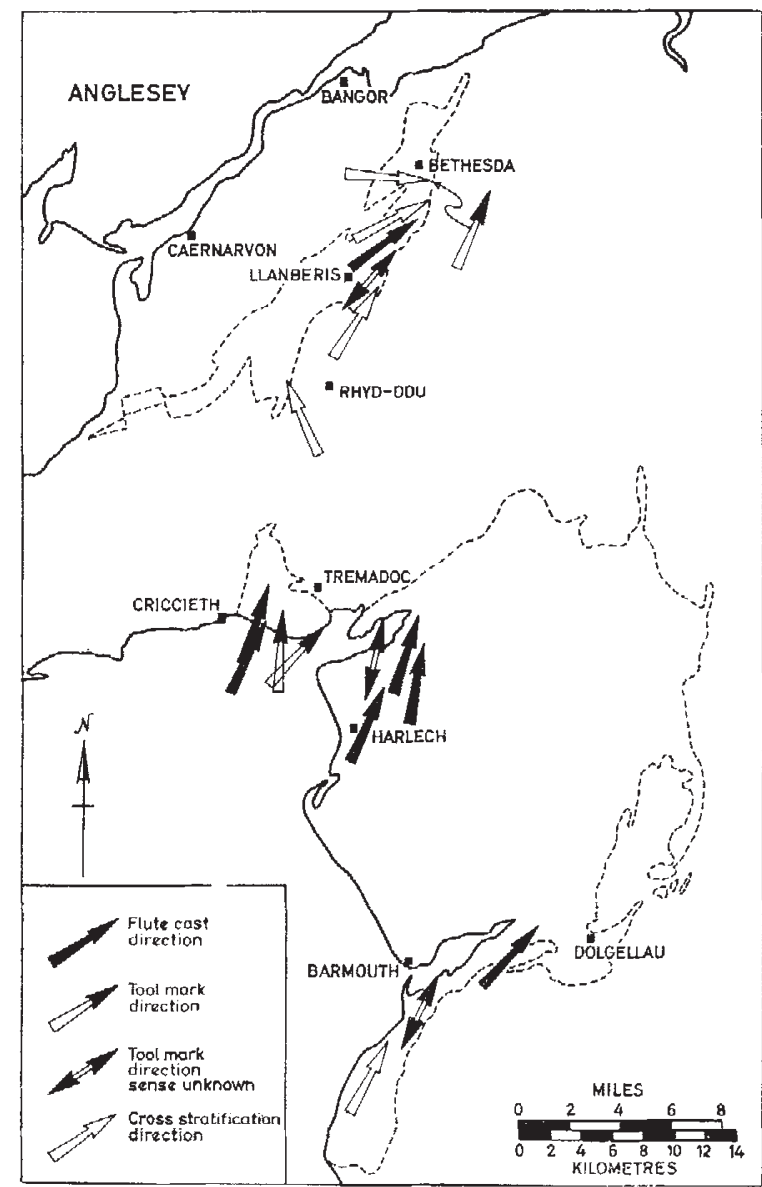

Ijig. 1. Palaeocurrent directions for Maentwrog and Ffestiniog Reds, The arrow south-east of Rethesda is displaced for greater clarity) trace fossils, flute, groove, striation, prod and brush casts. Ball-and-pillow structure, load casts and flame structures are present. Fig. 1 summarizes the measurements on the directional struotures and shows clearly that currents came generally from the south-soubh-west. The four different arrow symbols represent the four commonest dircctional structures, namely, flutc casts, tool marks (prod casts showing polarity and striation casts without polarity) and the dip direction of small-seale forcset beds. Tho directions in which the arrows point represent the original azimuths after climination of bedding dip and, where possible, plunge.

The tops of some of the thick, conrse-grained Ffestiniog greywackes in the northern half of the area show well. developed asymmetrical ripple marks, like the spectacular bedding surface in Cwm Graianog deseribed by Williams"; but their trend is not at right angles to the current direotions as indicated by sole markings and eross-stratificntion. Anomalous current directions for the tops of a number of British turbidites have boen discussed by Kelling. $\mathrm{He}$ invokes surge-waves, set up by the nose of a turbidity current, which are reflected back from the marginal slopes of the trough and deposit matorial showing current ripple marks at an oblique angle to the flow direction of the turbidity current. Similar anomalous directions aro noted by Whitaker ${ }^{4}$ frorn the Llandovery calcareous siltstones in South Norway, and the same process may account for the Uppor Cambrian occurrences in North Wales.

In the St. David's area of South Walcs, Farshoris has measured a number of directional structures in the equivalents of tho Maentwrog and Ffestiniog Beds and deduced currents moving from between west-south-west and south-south-west comparable with those in North Wales recorded here.
A. M. Evans
P. GarRETT
J. H. MCD. Whitaker

Department of Geology,

University of Leicester.

${ }^{1}$ Crimes, T. P., and Sly, P. G., Nature, 204, 174 (1964).

${ }^{2}$ Williams, D., Quart. J. Geol. Soe., 86, 191 (1930).

"Kelling, G., in Turbidites, edit. by Bouma, A. H., and Brouwer, A., 84 (Eisevier, Amstcrdam and New York, 1964).

-Whitaker, J. H. McD., Nature, 20\%, 709 (1985)

Farshori, M. Z. U., thesis, Univ, London (1902).

\section{CRYSTALLOGRAPHY}

\section{Structures of 5-Bromodeoxyuridine and 5-Bromouridine}

Halogenated deoxyuridines can be incorporated into DNA in place of the normal thymidine component, and this affects the physical properties of the DNA and has important biological consequences. For example, it makes DNA more sensitive to ultra-violet radiation ${ }^{2}$ and it produces mutagenic changes ${ }^{2}$.

By means of $X$-ray crystal analysis we have invostigated the structure of 5-bromodeoxyuridine (BUDR) and that of the closely related 5-bromouridine (BUR). These moleculos differ by only one oxygen atom (Fig. 1), and it is of interest to see what differences exist between their conformations. BUDR can exist in more than one crysta] form, and that studied by us is different from the one mentioned by Camerman and Trotter ${ }^{\mathbf{3}}$, who determined the structure of 5-iododeoxyuridine. They obtained triclinic erystals with unit coll dimensions of $a=4.87 \AA$ $b=6.72 \AA, c=9.56 \AA, \alpha=100^{\circ} 10^{\prime}, \beta=107^{\circ} 24^{\prime}$, $\gamma=98^{\circ} 31^{\prime}$.

Crystals of BUDR and BUR were obtaincd from aqueous solutions by slow evaporation. The unit cells are monoclinic with the following dimensions:

BUDR $a=9 \cdot 150 \AA, b=5 \cdot 142 \AA, c=12 \cdot 108 \AA, \beta$ $108 \cdot 2^{\circ}$

$\mathrm{BUR} a=7.725 \AA, b=5.813 \AA, c=13.264 \AA, \beta=101.2^{\circ}$ 